Agricultural Journal 6(4): 177-180, 2011

ISSN: $1816-9155$

(C) Medwell Journals, 2011

\title{
Toxicity of 2,4-Dichlorophenoxyacetic Acid on African Mud Fish Clarias gariepinus (Teugals)
}

\author{
Sani Mallum Shallangwa \\ Third National Fadama Development Project, 77 Lamibo Street, \\ Yola Town, Adamawa State, Nigeria
}

\begin{abstract}
The acute and sub-lethal toxicity of a herbicide 2,4-Dicholorophenoxyacetic acid (2,4-D) to juveniles of Clarias gariepinus (Teugels) of mean weight of $26.62 \pm 1.25 \mathrm{~g}$ and standard length of $14.83 \pm 0.04 \mathrm{~cm}$ were investigated under laboratory condition. In $96 \mathrm{~h}, \mathrm{LC}_{50}$ was $86 \mathrm{mg} \mathrm{L}^{-1}$. The toxicant led to initial increase in the opercular ventilation rate which then decreased below the status quo by the end of the $96 \mathrm{~h}$. Restlessness, immobilisation, loss of balance and air gulping were commonly observed before death during the acute bioassay. Exposed cells of the fish gill had coagulation necrosis of the lamellae, perilamellae fibrosis and inflammations. In addition, dose-dependent necrosis of adductor muscles was observed at the highest acute concentration ( $86 \mathrm{mg} \mathrm{L}^{-1}$ ).
\end{abstract}

Key words: $2,4-\mathrm{D}$, toxicity, Clarias gariepinus, lamellae, perilamellae fibrosis, adductor muscles, Nigeria

\section{INTRODUCTION}

The choice of the herbicide 2,4-Dichlorophenoxyacetic acid for this study is because it is widely used in the control of wide variety of broad leaf weeds in this country both upland and in fadama for the cultivation of rice. Therefore, there is the need for studies to be carried out to determine the effect of the various chemicals on aquatic life, especially fish. Information emanating from such research is required to provide baseline data on pesticides produced in the developed world for developing and underdeveloped worlds (USEPA, 2000). Acute toxicity tests are carried out in the laboratory to determine the $\mathrm{LC}_{50}$ that is concentration that will kill $50 \%$ of the fish or test organism under specified condition as observed by Lloyd. The period of exposure is usually 24 , 48 or $96 \mathrm{~h}$ and the fish are not fed during the tests.

Each pesticide exhibit different level of toxicity depending on the fish species. For example, Ufodike and Omorege reported that Gammalin 20 was found to be more toxic than Actellic $25 \mathrm{EC}$ when the two pesticides were exposed to Oreochromis niloticus in an acute toxicity bioassay. The mortalities and $\mathrm{LC}_{50}$ of fishes exposed to different pesticides vary. For instance in $96 \mathrm{~h}, \mathrm{LC}_{50}$ of Oreochromis niloticus when exposed to paraquat was $3.56 \mathrm{mg} \mathrm{L}^{-1}$ while that of C. gariepinus exposed to diazinon was $6.03 \mathrm{mg} \mathrm{L}^{-1}$ (Okeke, 2004).

Murty (1986) reported that in $96 \mathrm{~h}, \mathrm{LC}_{50}$ of endrin to various species of fish ranged from $0.7-2.1 \mathrm{mg} \mathrm{L}^{-1}$ under static condition while toxicity of 2,4-D depends on the type of formulation used. About 2,4-Dichlorophenoxyacetic acid $(2,4-D)$ products generally contain one or more inert ingredients. An inert ingredient is anything added to the product other than an active ingredient. Two of the formulated 2,4-D concentrations are listed and one of the concentrations was used in this experiment:

- Weeder 64 (liquid): Dimethylamine salt of 2,4-D $(46.8 \%)$ and inert $(53.2 \%)$

- HIDEP (liquid): Dimethylamine salt of 2,4-D (33.2\%) diethanol amine salt of 2,4-D (16.3\%) and ethylene glycol $(10 \%)$, other inert $(40.3 \%)$ (b is used in this study)

\section{MATERIALS AND METHODS}

Experimental fish: Fingerlings of Clarias garpinus with average standard length of $15.75 \pm 0.65 \mathrm{~cm}$ and body weight of $24.62 \pm 1.07 \mathrm{~cm}$ used for the study were obtained locally from Maigana Fish Farm near Zaria. The experimental fish were conveyed to the Fisheries Laboratory, Department of Biological Sciences, Ahmadu Bello University Zaria in plastic jericans.

The fish were held in the laboratory in one large water bath of $160 \mathrm{~L}$ capacity. During acclimatization for 2 weeks, three quarters of the test water was changed daily by siphoning out the spent water. The tank was checked daily for fish, mortality as recommended by Sprague. During this period, the fish were fed with pelleted feeds containing $35 \%$ crude protein.

Sublethal bioassay exposure

Experimental set up: Four aquaria tanks with dimension $30 \times 30 \times 45$ were set up. The nominal concentrations of 
2,4-D used were $2.89,3.62$ and $4.83 \mathrm{mg} \mathrm{L}^{-1}$, one of the four tanks served as control. The bioassay was conducted in triplicate. A total of 120 juveniles of Clarias gariepinus were sorted randomly into the glass tanks at 10 fish $\operatorname{tank}^{-1}$. A major difference in this study was the use of aerators for continued aeration of water throughout the duration of the experiment unlike the previous study where no aeration took place.

Experimental tanks were cleaned every 2 days before 1 st feeding by siphoning dirt, unconsumed feed and faeces with flexible hose. The water level in the tanks were then maintained by adding fresh water from the reservoir and appropriate volumes of the toxicant added into each tanks, except the control tanks.

Acute toxicity: Acute $96 \mathrm{~h}$, static bioassays were conducted in the laboratory as described by Sprague and APHA to determine the toxicity of 2, 4-D to C. gariepinus. In the bioassay test, carried out six glass tanks of size $30.5 \times 30.5 \times 92.5 \mathrm{~cm}$ were used for the study, five containing different concentration of the toxicant and the 6 th tank had no toxicant (control). The bioassay was conducted in duplicate. The desired 2,4-D concentrations were measured and introduced into $50 \mathrm{~L}$ of dechlorinated and aerated tap water in the glass tanks. The nominal concentrations for 2, 4-D used for C. gariepinus were $0.00,57.6 \mathrm{mg}, 64.8,72.0,79.2$ and $84.4 \mathrm{mg} \mathrm{L}^{-1}$. The mixture was allowed to stand for $30 \mathrm{~min}$ before introducing test organisms (C. gariepinus). Thereafter, the tanks were stocked at 10 fish tank $^{-1}$ for the experimental run.

Statistical analysis: Analysis of Variance (ANOVA) and Duncan multiple range tests were employed to test for the relationship between the various parameters. Test of significance were at $95 \%$ probability. Regression coefficient between the probit kill and $\log$ concentration of the toxicant was determined after the acute toxicity bioassay. Differences between treatments (CRD). Correlation coefficient ( $\mathrm{r}$ ) was used to determine.

\section{RESULTS}

\section{Acute toxicity test}

Behaviour: The fish remained calm or motionless for some few minutes then became restless and agitated immediately, they were introduced into the test tanks which contained different concentration of 2,4-D. Other behaviours were irregular, erratic movement and coming to the surface to gulp air. With increased exposure time, the fish were in vertical position with their heads above the water surface. Their activities later decreased and became sluggish resulting into loss of equilibrium, swelling and whirling of the body in a circular motion and then finally death. Whitish mucus oozed out of the gill filament and the body surfaces and this increased with the increasing concentration of the 2,4-D.

Respiration rates: The results of the opercular ventilation and the tail fin beats are shown in Table 1. Table 1 showed that the opercular beats and the tail fin beats of the fish, exposed to the toxicant at 12 and $24 \mathrm{~h}$ were slightly higher than the one in the control fish. As the concentration of 2,4-D increases, the beats of the tail and operculum increases, except at the 48 th $\mathrm{h}$ when the beats started to decrease.

With increased in exposure time, the opercular and tail fin beats decreased as compared to the control as shown in the Table 2. The values of the beats were dose dependent. Throughout the test period, the control was more or less the same while the values of the exposed fish were high during the 1 st $24 \mathrm{~h}$ but reduced steadily with the increase in the time of exposures as seen in the 48,72 and 96th $\mathrm{h}$.

\section{Effects of sub-lethal concentrations}

Behavioural responses: At sub-lethal concentrations of the toxicant exposed to C. gariepinus, fish behaviour at 2.89 and $3.62 \mathrm{mg} \mathrm{L}^{-1}$ appeared normal. At $4.83 \mathrm{mg} \mathrm{L}^{-1}$ (the highest sub-lethal concentration) some abnormal behaviour such as hyperactive responses were observed such as agitated swimming coming to the surface to gulp air.

Mortality rates: The mean mortality rates of C. gariepinus exposed to sub-lethal concentrations of 2,4$\mathrm{D}$ is shown in Table 3. There was no mortality in the control group of fish while low mortalities were observed in the exposed group though, lower compared to acute concentrations. Mortalities were observed only within the 1 st 4 weeks in the exposed fish but none from 5-8.

\section{Histopathology}

Gills: The gills of the control fish (Fig. 1a, b) had normal filamental and lamella structure. But there were marked differences between the gills of the control fish and those exposed to various acute concentrations of the toxicant, especially at higher concentrations of the toxicant. The lamellae were greatly distorted (Fig. 1a), they had coagulation necrosis, perilamellae fibrosis and inflammatory cells. In addition, necrosis of adductor muscle were observed at the highest acute concentration (86 $\mathrm{mg} \mathrm{L}^{-1}$ ) of the toxicant (Fig. 1b). 
Agric.J., 6 (4): 177-180, 2011

Table 1: Mean opercular and tail fin beats of C. gariepinus exposed to acute concentration of 2, 4-D Exposure period (h)

\begin{tabular}{|c|c|c|c|c|c|c|}
\hline \multirow[b]{2}{*}{ Parameters } & \multicolumn{6}{|c|}{ Exposure period (h) } \\
\hline & 0 & 12 & 24 & 48 & 72 & 96 \\
\hline Opercular beats & $84.25 \pm 2.32$ & $86.50^{9} \pm 0.2$ & $83.83^{b} \pm 1.15$ & $75.16^{\mathrm{c}} \pm 1.02$ & $73.67^{\mathrm{d}} \pm 1.52$ & $73.00^{\mathrm{d}} \pm 4.20$ \\
\hline Tail fin beats & $84.32 \pm 3.01$ & $86.83^{\circ} \pm 2.01$ & $84.17^{b} \pm 2.31$ & $66.00^{c} \pm 2.23$ & $64.33^{\mathrm{d}} \pm 3.21$ & $63.50^{\mathrm{d}} \pm 1.52$ \\
\hline
\end{tabular}

Means with the same letter along the same row are not significantly different $(p>0.05)$

Table 2: Mortality of Clarias gariepinus juveniles exposed to acute concentration of 2, 4-D for $96 \mathrm{~h}$

\begin{tabular}{|c|c|c|c|c|c|c|c|c|c|c|c|c|}
\hline \multirow{4}{*}{$\begin{array}{l}\text { Exposure } \\
\text { period (h) }\end{array}$} & \multicolumn{12}{|c|}{ Concentration $\left(\mathrm{mg} \mathrm{L}^{-1}\right)$} \\
\hline & \multicolumn{2}{|l|}{0.00} & \multicolumn{2}{|l|}{57.6} & \multicolumn{2}{|l|}{64.8} & \multicolumn{2}{|l|}{72.0} & \multicolumn{2}{|l|}{79.2} & \multicolumn{2}{|l|}{86.4} \\
\hline & $\cdots$ & --- & $\cdots+\cdots$ & -.-- & $\cdots-\cdots$ & $\cdots$ & $\cdots-\cdots$ & & $-\cdots$ & & 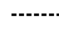 & -..--.. \\
\hline & $\mathrm{R}_{1}$ & $\mathrm{R}_{2}$ & $\mathrm{R}_{1}$ & $\mathrm{R}_{2}$ & $\mathrm{R}_{1}$ & $\mathrm{R}_{2}$ & $\mathrm{R}_{1}$ & $\mathrm{R}_{2}$ & $\mathrm{R}_{1}$ & $\mathrm{R}_{2}$ & $\mathrm{R}_{1}$ & $\mathrm{R}_{2}$ \\
\hline 12 & - & - & 1 & - & - & 1 & - & 1 & - & 2 & 2 & 1 \\
\hline 24 & - & - & - & 1 & - & - & 1 & - & 3 & 3 & 3 & 6 \\
\hline 48 & - & - & 1 & 1 & - & 1 & 2 & - & 2 & - & 2 & - \\
\hline 72 & - & - & - & - & 2 & - & 1 & - & 2 & 1 & - & 1 \\
\hline 96 & - & - & - & - & - & 1 & - & 3 & - & 1 & 2 & - \\
\hline Mortality & $0 / 10$ & $0 / 10$ & $2 / 10$ & $2 / 10$ & $3 / 10$ & $3 / 10$ & $4 / 10$ & $4 / 10$ & $7 / 10$ & $6 / 10$ & $9 / 10$ & $8 / 10$ \\
\hline $\begin{array}{l}\text { Mean } \\
\text { mortality }\end{array}$ & $0 / 10$ & & $2 / 10$ & & $3 / 10$ & & $4 / 10$ & & $6 / 10$ & & $8 / 10$ & \\
\hline
\end{tabular}

$\mathrm{R}_{1}=$ Replication $1 ; \mathrm{R}_{2}=$ Replication 2

Table 3: Mortality record of Clorias goriepinus exposed to sub-lethal concentrations of 2,4-D for 8 weeks

\begin{tabular}{lcccc}
\hline \multicolumn{5}{c}{ Concentrations of $2,4-\mathrm{D}$ for 8 weeks } \\
& Concentration $\left(\mathrm{mg} \mathrm{L}^{-1}\right)$ & & \\
& - & & \\
Exposed period (weeks) & 0.00 & 2.89 & 3.62 & 4.83 \\
\hline 1 & 0.00 & 0.33 & 0.67 & 1.00 \\
2 & 0.00 & 0.33 & 0.33 & 0.67 \\
3 & 0.00 & 0.00 & 0.33 & 0.33 \\
4 & 0.00 & 0.00 & 0.00 & 0.33 \\
5 & 0.00 & 0.00 & 0.00 & 0.00 \\
6 & 0.00 & 0.00 & 0.00 & 0.00 \\
7 & 0.00 & 0.00 & 0.00 & 0.00 \\
8 & 0.00 & 0.00 & 0.00 & 0.00 \\
Means & 0.00 & 0.33 & 0.44 & 0.60 \\
Percentage mortality (\%) & 0.00 & 0.33 & 0.44 & - \\
\hline
\end{tabular}

\section{DISCUSSION}

Clarias gariepinus exposed to lethal concentrations of 2,4-D exhibited agitated swimming, loss of equilibrum, air gulping, period of quiescence and the fish turned on its flank and swarm in circles and finally died. Hyper activity was the most common response of 2,4-D effect on C. gariepinus and was dose dependent. Such activity was also reported by Matsumara (1975) to be the primary and principal sign of nervous system, failure due to pesticide poisoning which affects physiological and biochemical activities in non-target organisms.

Pal and Konar (1987) opined that disruption of the functioning of the nervous system of fish might be the cause of slow and agitated swimming, erratic movement and loss of equilibrum. Accumulation of mucus also was observed on the gill filaments and body surface of the dead fish after their exposure to the lethal concentration of 2,4-D. Hossain et al. (1987) stated that increase in production of mucus over the body as a result
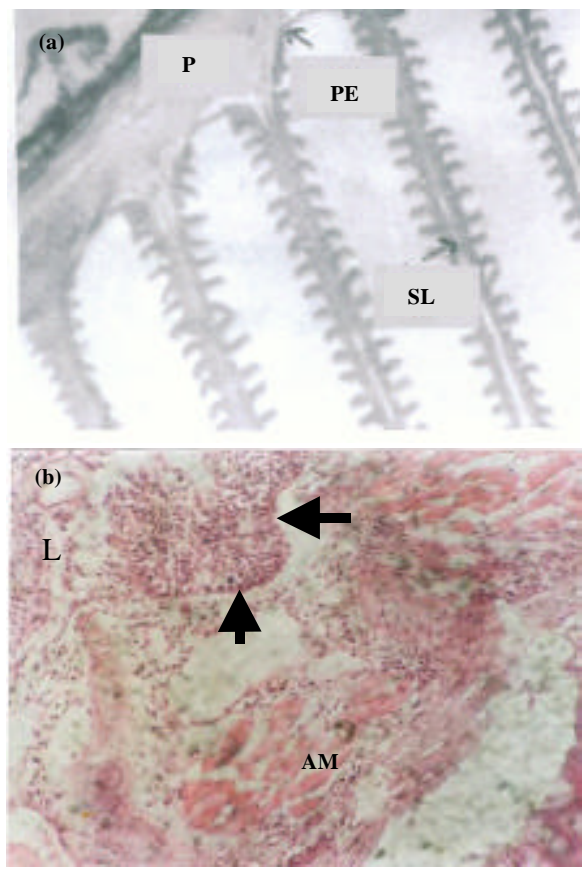

Fig. 1: a) T.S. of gill of Clarias gariepinus of control fish showing normal distribution of cells. $\mathrm{H}$ and $\mathrm{E}$ stain. $\mathrm{X} 400 ; \mathrm{SL}=$ Secondary Lamella; $\mathrm{PE}=$ Primary Epithelium; P = Primary Lamella. Note the normal width of the primary lamella $\times 240$; b) Photomicrograph of a section of gill from Clarias gariepinus exposed to $86.4 \mathrm{mg} \mathrm{L}^{-1}$ of 2,4-D. Note the necrosis of the Adductor Muscle (AM), necrosis of the Lamellae (L) and the inflammatory cells (arrow heads). $\mathrm{H}$ and $\mathrm{E}$ stain. X400

of toxicant may interfere with the gaseous exchange, secretion and waste products and osmoregulation. The results of the opercular and tail fin beats also showed that increase in time of exposure resulted in decrease of opercular and tail fin beats in C. gariepinus, this suggests decreased oxygen consumption and reduced energy. The reduction of respiratory rate implies that the fish had become fatigued due to several attempts to escape from the toxic medium to facilitate more oxygen intake. These behavioural patterns are indicative of respiratory impairment due to the effect of the toxicant on the gills and general metabolism (Chindah et al., 2004). Exposed cells of the fish gills to acute concentration of 2,4-D in C. gariepinus had oedema and hyper plasia of the 
gill lamellae resulting in necrosis of the lamellae, perilamelae fibrosis and inflammatory cells and necrosis of the adductor muscle. Similar, damage in C. gariepinus exposed to dimethoate was reported by Auta (2001). The damage to the gills could be responsible for the hyper respiratory and osmoregulatory activities of the fish which led to fatique and finally death of some of the fish. These findings are similar to that reported by Omoregie and Ufodike (1991). But sub-lethal concentration of the herbicide to the fish did not induce any observable pathological defect.

\section{CONCLUSION}

Minor damages were observed at the sublethal bioassay while no damage was apparent at lower concentrations. Damages to the lower cells of the fish, exposed to lethal concentrations of the toxicant included disruption of the hepatocytes, necrosis and reduced liver vacuolation.

\section{REFERENCES}

Auta, J., 2001. Toxicity of dimethoate to juveniles of Oreochromis niloticus (Trewaves) and Clarias gariepinus (Teugels). Ph.D. Thesis, Biological Science Department, Ahmadu Bello University Zaria, Nigeria.
Chindah, A.C., F.D. Sikoki and I. Vincent-Akpu, 2004. Toxicity of an Organophosphate Pesticide (chloropyrifos) on a common Niger Delta Wetland Fish-Tilapia guineensis (Blecker 1862). J. Applied Sci. Environ. Mgt., 8: 11-17.

Hossain, M.M., D.B. Ghatak and S.K. Konar, 1987. Acute toxicity of mixture of non-ionic detergent ekatine and an organic pesticides DDVP to Fish, plankton and worm. Environ. Ecol., 5: 778-781.

Matsumara, F., 1975. Toxicity of Insecticides. Plenuim Press, New York, pp: 415.

Murty, A.S., 1986. Toxicity of Pesticides to Fish. Vol. 2, CRC Press, Boca Raton, Florida, ISBN-13: 9780849360596, pp: 160.

Okeke, P.U., 2004. Toxicity of Diazinon to juveniles of African cat fish, Clarias gariepinus (Teugels). M.Sc. Thesis, Ahmadu Bello University.

Omoregie, E. and E.B.C. Ufodike, 1991. Histopathology of O niloticus exposed to Acetellic 25EC. J. Aquatic Sci., 6: 13-17.

Pal, A.K. and S.K. Konar, 1987. Long-term effects of organophosphrous insecticide, methyl parathion on fish. Environ. Ecol., 513: 564-517.

USEPA, 2000. Pesticides Fact Sheet No. 72: Monocrotophos. US Environmental Protection Agency. 